\title{
Aliskiren - an alternative to angiotensin-converting enzyme inhibitors or angiotensin receptor blockers in the therapy of arterial hypertension
}

Iwona Zaporowska-Stachowiak', Karolina Hoffmann², Wiesław Bryl2, Andrzej Minczykowski ${ }^{3}$

${ }^{1}$ Chair and Department of Pharmacology, Poznan University of Medical Sciences, Poland

${ }^{2}$ Chair and Department of Internal Medicine, Metabolic Disorders and Arterial Hypertension, Poznan University of Medical Sciences, Poland

${ }^{3}$ Department of Cardiology-Intensive Therapy, Poznan University of Medical Sciences, Poland

Submitted: 18 September 2012

Accepted: 20 December 2012

Arch Med Sci 2014; 10, 4: 830-836

DOI: $10.5114 /$ aoms.2013.34723

Copyright (c) 2014 Termedia \& Banach

\author{
Corresponding author: \\ Iwona Zaporowska- \\ Stachowiak MD, PhD \\ Chair and Department \\ of Pharmacology \\ Poznan University \\ of Medical Sciences \\ $5 \mathrm{~A}$ Rokietnicka St \\ 60-806 Poznan, Poland \\ Phone: +48 618547262 \\ Fax: +48 618547252 \\ E-mail: iwozapor@amp.edu.pl
}

\begin{abstract}
There has been enormous progress in antihypertensive therapy over the last few decades. However, the management of arterial hypertension is still insufficient and more efforts are needed to improve both non-pharmacological and pharmacological treatment of this widely prevalent disease. Renin-angiotensinaldosterone system (RAAS) inhibition is crucial both for blood pressure (BP) control and for prevention of organ damage or its development in patients with hypertension. Angiotensin-converting enzyme inhibitors and/or sartans block RAAS incompletely. Aliskiren is one of the novel drugs that has been introduced to antihypertensive therapy recently. Up to now no trial has confirmed that aliskiren is efficacious in reducing cardiovascular events. Double RAAS blockade with aliskiren was not always safe. This review article presents the current view on the place of aliskiren in the therapy of arterial hypertension.
\end{abstract}

Key words: antihypertensive therapy, renin-angiotensin-aldosterone system, renin inhibitor.

\section{Introduction}

Essential hypertension (EH) is a major risk factor for cardiovascular diseases and related disorders and the most frequent cause of death worldwide. The WHO data show that EH was the cause of 7.1 million deaths ( $13 \%$ of all deaths), $62 \%$ of all strokes and $49 \%$ of all myocardial infarctions (MI) [1]. In 2004, 65.2 million Americans (31.3\% of the adult population) had EH [2]; $44.2 \%$ of people aged 35-75 were diagnosed with $\mathrm{EH}$ in analysis conducted in 6 European countries [3]. Essential hypertension is the second most frequently detected cardiovascular risk factor in the Polish population. According to the NATPOL 2011 study, 32\% of adults under 80 years were diagnosed with $\mathrm{EH}[4]$.

According to WHO, 27\% of the population were diagnosed with $\mathrm{EH}$ but not treated, while $28 \%$ of men and $37 \%$ of women were undertreated. Essential hypertension control was proper in $9 \%$ of males and $14 \%$ of females [5]. Antihypertensive therapy is expected to meet target blood pressure (BP) and reduce cardiovascular endpoints, i.e. stroke, myocardial infarction and heart failure. Monotherapy achieves this goal in $26-33 \%$ of patients, while $45 \%$ and $22 \%$ of hypertonics require 2 or $\geq 3$ agents, respectively [6]. High- 
risk patients with hypertension (coexisting coronary artery disease, heart failure, diabetes mellitus, chronic hypertensive cardiovascular disease, stroke) should be carefully selected for both specific drug(s) use and BP targets due to potential adverse effects and the J-curve phenomenon [7].

Depending on a patient's age, in this group, BP should be reduced below 140/90 $\mathrm{mm} \mathrm{Hg}(<80$ years), and to $140-145 \mathrm{~mm} \mathrm{Hg}$ (systolic, if tolerated among patients $>80$ years) [8]. Blood pressure decreased below 110-115/70-75 brings a risk of increased incidence of cardiovascular events [7]. For resistant hypertension, non-pharmacological methods were also introduced - an implantable device which stimulates the carotid baroreceptors or catheter-based radiofrequency ablation of the renal sympathetic nerves - but their safety and long-term efficacy are subject to debate [6]. This situation gives rise to the need for optimization of treatment and research on new antihypertensive drugs. Studies into the nature of drugs exerting an impact on the renin-angiotensin-aldosterone system (RAAS) became a milestone in $\mathrm{EH}$ pharmacotherapy. Reninangiotensin-aldosterone system inhibition improves both the clinical condition and the prognosis for $\mathrm{EH}$ patients, because it lowers BP and prevents organ damage or its development [9].

\section{Renin-angiotensin-aldosterone system}

Renin-angiotensin-aldosterone system, a group of proteins in the circulatory system, undergoes cascade reactions, which result in the formation of angiotensin II (AngII) and aldosterone. Two independent RAASs, intravascular and endocrine, play a role in the BP, water-electrolyte balance, and in the local tissue autoand paracrine system - crucial for physiological processes (brain development, learning, memory boost and tissue growth), and for inflammation, small and large vessel hypertrophy and remodeling and obesity [10]. The RAAS may be pharmacologically influenced on the following levels [11-14]:

1. inhibition of renin release from the renal juxtaglomerular apparatus ( $\beta$-blockers use);

2. renin inhibition (angiotensinogen analogs $=$ renin inhibitors use);

3. competitive inhibition of the ACE enzyme and decreased Angll formation (angiotensin-converting enzyme inhibitors - ACEI);

4. block of renin binding to the angiotensin type 1 receptor $\left(A T_{1} R\right)$, no angiotensin type 2 receptor $\left(A T_{2} R\right)$ stimulation prevention (Angll antagonists, angiotensin receptor blockers - ARBs);

5. block of the mineralocorticoid receptor (MR) (aldosterone antagonists use).

\section{Renin}

Renin, an aspartate protease, highly specific towards its only substrate, angiotensinogen, is the key, first rate-limiting step enzyme of the biochemical RAA cascade, an important BP regulator. High serum renin activity (SRA) per se might be a risk factor for cardiovascular diseases. Alderman et al. found that the SRA value, before the antihypertensive treatment of 2902 hypertonics, was directly correlated with the risk of myocardial infarction (MI), despite optimal BP control [15]. A link between high SRA and kidney dysfunction and left ventricle hypertrophy was demonstrated $[16,17]$. The RAAS blockade is not full and longterm when an ACEI is used: the reactive serum renin rise results in increased Angl formation, which boosts Angll synthesis through the ACE dependent and independent pathways (i.e., tissue chymases) [18]. The degree of compensatory renin release is proportional to the decrease of Angll, generated or bound to the $A T_{1} R$ in the renal juxtaglomerular apparatus.

\section{The history of renin inhibitors' development}

In 1957 Seggs et al. stated: “...the production of hypertensin I from renin substrate might be prevented by the inhibition of renin. Since renin is the initial and rate-limiting substance in the reninangiotensin system, it seems that this last approach would be the most likely to succeed. This view is reinforced by the observation that immunization with heterologous renin has been used successfully in the treatment of dogs with experimental renal hypertension" [19].

In the last 30 years many renin inhibitors have been synthesized and studied (enalkiren, remikiren, terlakiren, zankiren), but they did not become clinically useful because of their low efficacy, low bioavailability, short duration of action after oral use and high costs of synthesis [20, 21]. Further research on renin inhibitors' molecular modifications were focused on solving the problem of bioavailability of the drugs. X-ray crystallography and computer-aided molecular design methods (for the reconstruction of enzyme active center structure) were used in the Hoffmann-La Roche laboratory to synthesize piperidine renin inhibitors, which have only gone through preclinical trials [22]. A non-peptide, orally active compound, aliskiren (CGP 60536 B) was discovered in Ciba-Geigy (now Novartis) by using the same methods of preparation [23]. Aliskiren synthesis was not suitable for mass production since it was multilevel and costly. In 1999 Speedel AG took over the license for aliskiren production and developed a cost-effective method of its synthesis [24]. In 2001 Hoffmann-La Roche discovered a new subclass of renin inhibitors, SPP600 series, and in 2005 Speedel AG synthesized another series of compounds with analogous effects, SSP800 [25]. 


\section{Aliskiren}

Aliskiren (SPP100), an octanamide, is the first representative of the new class, non-peptidic, low molecular weight, specific, orally active renin inhibitors which made it through to the third phase of clinical trials [26]. The drug is hydrophilic, refractory to intestine, serum and hepatic peptidases biodegradation, and its inhibitory concentration of $50 \%$ (IC50) is measured in the low nanomolar range [27]. Studies in healthy volunteers [27] showed that with aliskiren doses from 40 to $640 \mathrm{mg}$ daily there was a dose-related increase of its serum level, with maximum concentration within 3-6 $\mathrm{h}$ after the drug administration. Plasma steady-state concentrations were achieved within 5-8 days during the drug use and oral bioavailability of aliskiren in the single dose of $75 \mathrm{mg}$ was $2.6 \%$. Aliskiren may be administered once a day (half life $=20-45 \mathrm{~h}( \pm 23.7)$ ) [27], does not influence cytochrome P450 isoenzymes, underwent hepatic metabolism to a minimal extent, and is moderately bound by the serum proteins; thus no pharmacokinetic interactions between aliskiren and co-administered drugs (e.g., warfarin) were observed [28]. After oral administration, aliskiren is eliminated unchanged, mainly with bile (less than $1 \%$ excreted with urine) [27]. Patients in all age groups tolerate aliskiren well. Vaidyanathan et al. reported that no dose adjustment of aliskiren is needed for patients aged 65-74 and older [29]. Ethnicity seems to have no influence on pharmacokinetic and pharmacodynamic properties of aliskiren, as they are similar in Caucasian and Japanese populations [29].

\section{Selected data concerning aliskiren}

Aliskiren caused prolonged, dose-dependent inhibition of RAAS in healthy volunteers [27]. Azizi et al. [30] compared the influence of monotherapy with aliskiren (300 mg daily) or valsartan (160 mg daily), or of both drugs co-administered in half doses on serum renin, angiotensins, aldosterone levels and SRA, which were initially high. A single aldosterone dose, after $1 \mathrm{~h}$, caused total inhibition of SRA, which lasted for $48 \mathrm{~h}$. Valsartan administration caused SRA increase within $4 \mathrm{~h}$, followed by higher than after placebo use SRA increase for $48 \mathrm{~h}$. Combination therapy lowered SRA $1 \mathrm{~h}$ after the drugs administration to a level lower than in the placebo group. Aliskiren increased renin serum concentrations far more than valsartan: 15 -fold and 10 -fold, respectively. When compared with valsartan, aliskiren inhibited urine aldosterone excretion for a longer time ( $8 \mathrm{~h}$ and $48 \mathrm{~h}$, respectively). Combination therapy had similar hypotensive efficacy as monotherapy with aliskiren, and more positive results than the sole use of $160 \mathrm{mg}$ of valsartan. Thus, co-administration of inhibitor (150 mg of ali- skiren) and Angll inhibitor (80 mg of valsartan) in small doses acts synergistically on RAAS [30]. Stanton et al. examined 226 hypertensives (mildto-moderate EH), treated with 300 mg of aliskiren daily. The BP decrease was comparable to that obtained with higher than recommended losartan doses [31]. The investigation by Gradman et al. revealed that 2-week treatments of patients with mild-to-moderate $\mathrm{EH}$, with different aliskiren single daily doses (150 mg, $300 \mathrm{mg}, 600 \mathrm{mg}$ ), were effective and safe similarly to a single daily dose of $150 \mathrm{mg}$ of irbesartan [32]. Selected clinical trials concerning aliskiren use in mild-to-moderate $\mathrm{EH}$ are presented in Table I.

\section{Aliskiren - hypotensive effects}

The Musini et al. meta-analysis of studies assessing aliskiren, used for 4-8 weeks in daily doses of 75-600 mg, in 3694 adult patients with EH, confirmed significant, dose-dependent, hypotensive effects of aliskiren, as compared with placebo, which was comparable with the antihypertensive efficacy of ACEls and ARBs. During 4-8 weeks of observation, cessation of treatment because of drug adverse reactions was equally frequent in groups treated with aliskiren and placebo [34]. The metaanalysis of 10 clinical trials prepared by Gao et al., including 3732 hypertonics, confirmed similar antihypertensive efficacy and safety of aliskiren and $\mathrm{AT}_{2} \mathrm{R}$ blockers, namely losartan, valsartan and irbesartan [35]. Comparable hypotensive effects of aliskiren in both sexes (2064 males and $1527 \mathrm{fe}$ males) were found in Gradman's meta-analysis of 2010. Occurrence of aliskiren adverse effects in females and in the placebo group was similar, but more frequent in comparison with the males given aliskiren [36]. Stanton et al. (meta-analysis of data from 8 clinical trials) found that aliskiren monotherapy does not cause paradoxical, sudden increase of BP more often than monotherapies with other antihypertensive drugs, such as ACEls (ramipril), sartans (losartan, irbesartan, valsartan), or diuretics (hydrochlorothiazide) [37].

\section{Aliskiren - metabolic syndrome}

Aliskiren increased insulin sensitivity both in humans [38] and in animals on a high-fructose diet [39], due to decreased Angll formation. Chou et al. [39] demonstrated hypertension, hyperinsulinaemia, insulin resistance, hyperglycemia, hypercholesterolemia and hypertriglyceridaemia induced by persistent high-fructose diet in male Sprague-Dawley rats. All those metabolic disturbances were prevented or reversed by aliskiren in the dose of $100 \mathrm{mg} / \mathrm{kg} /$ daily s.c. for 4-8 weeks [39]. Stucchi et al. demonstrated reduction of plasma leptin levels and decreased insulin resistance fol- 


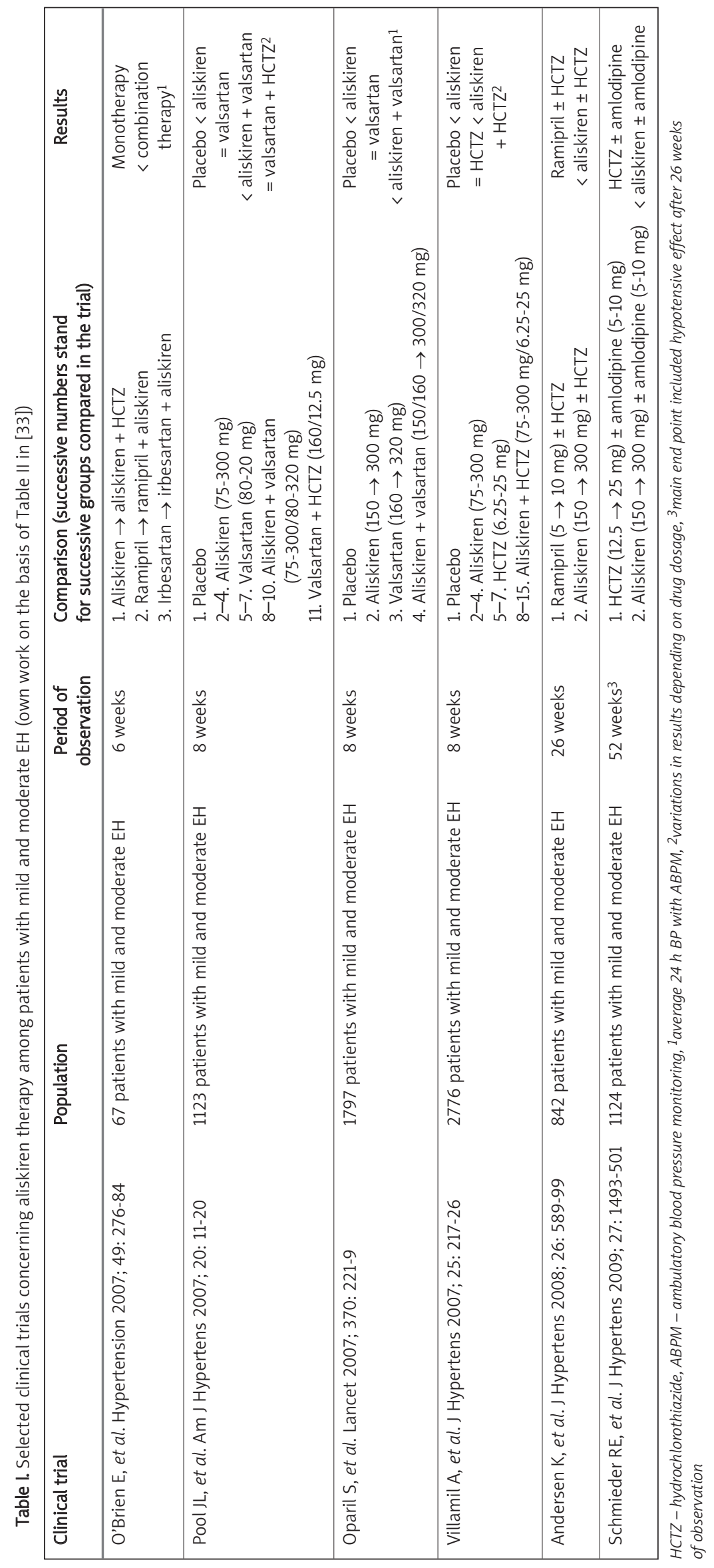


lowing aliskiren administration in obese mice on a high-fat diet [40].

\section{Aliskiren - cardio- and nephroprotective effects}

Studies assessing cardio- and nephroprotective effects of aliskiren, both in mono- and combination therapy with other RAAS blockers, have been conducted. ALLAY (Aliskiren in Left-Ventricular Hypertrophy Study), which included 465 obese patients with $\mathrm{EH}$ and left ventricular hypertrophy, concluded that aliskiren and losartan have a comparable effect on left ventricular hypertrophy regression and similar hypotensive efficacy and safety of use [41]. ALOFT (Aliskiren Observation of Heart Failure Treatment) compared the effects of aliskiren and placebo on the brain natriuretic peptide (BNP) serum concentration in patients with heart failure. Threemonth aliskiren therapy, as compared with placebo, statistically significantly decreased the concentration of BNP, N-terminal prohormone of brain natriuretic peptide (NT-proBNP), aldosterone and SRA [42]. In the AVOID program (Aliskiren in the Evaluation of Proteinuria In Diabetes Trial) aliskiren or placebo was combined with losartan, to assess the urine albumin-to-creatinine ratio of 599 hypertonics with type 2 diabetes mellitus and diabetic nephropathy. After 24 weeks of observation, in the group given aliskiren the urine albumin-tocreatinine ratio decreased $(-18 \%$ vs. $+2 \%$ - change of $20 \%$ ), which proves additional significant nephroprotective properties [43]. In the AVOID2 program, aliskiren's influence on renal blood flow and glomerular filtration rate (GFR) in diabetic patients with $\mathrm{EH}$, having estimated GFR (eGFR) over $40 \mathrm{ml} /$ $\min / 1.73 \mathrm{~m}^{2}$, was tested. After 2-month therapy, a decrease in urinary albumin excretion by $48 \%$, as compared with placebo, was noted. It has been shown that combining aliskiren and irbesartan (300 mg and $60 \mathrm{mg}$ daily, respectively) decreased albuminuria by $71 \%$, more efficiently than monotherapy [44]. The beneficial effects of aliskiren and its good tolerance in combination with sartans (valsartan, losartan) or a diuretic were confirmed in White's meta-analysis of July 2011, including over 12000 patients with $\mathrm{EH}$. Incidents of angioedema or hyperkalemia were noted equally frequently in groups treated with double RAAS blockade, as well as groups with sartan or diuretic monotherapy [45]. According to the statement of the European Medicines Agency of 17 February 2012, aliskiren coadministered with ACEIs or ARBs is not recommended in patients with diabetes (type 1 or 2) and moderate-to-advanced renal failure. The agency added a warning that a double RAAS blockade is not recommended in other patients, due to potential adverse effects: hypotension, fainting, stroke, hyperkalemia, and renal failure, including acute one. The opinion issued by the European Medicines
Agency is based on an analysis of data concerning safety of combining aliskiren with ACEls or ARBs, prepared after early termination of the ALTITUDE study in December 2011 [46]. Moist's meta-analysis of January 2012, including studies conducted with the use of aliskiren, ACEls and ARBs, concludes that combination therapy based on aliskiren and another drug blocking the RAAS far more often than monotherapy with any of these drugs leads to moderate (potassium concentration within the 5.5-5.9 $\mathrm{mmol} / \mathrm{l}$ range) hyperkalemia. No statistically significant differences in the occurrence of acute hyperkalemia ( $\geq 6.0 \mathrm{mmol} / \mathrm{l}$ ) or acute renal failure episodes were noted [47]. Significantly more frequent occurrence of hyperkalemia when using aliskiren in combination with ACEI or a ARB, as well as the necessity to carefully monitor serum potassium level among these patients, was confirmed by the meta-analysis of 10 clinical trials, including 4814 patients with EH, published also in January 2012 by Harel et al. In this analysis the risk of acute renal failure showed no statistically significant differences between the group given double RAAS blockade and the group with monotherapy (1.14, 0.68 to 1.89) [48]. Most recent analyses concerning renin inhibitors in nephroprotection emphasize that double blockade of the RAAS can be considered in cases of chronic nephropathy with albuminuria among patients who, despite treatment with an optimal dose of ACEl or sartan, do not achieve full and permanent albuminuria remission. The necessity to strictly monitor kalemia and renal function among these patients is stressed [49]. Because of the lack of suitable trials, aliskiren is still not included in ESH/ASH/ACC/ESC guidelines as a recommended therapy for HT treatment. So far no longterm data proving aliskiren to reduce cardiovascular events have been gathered. Thus, at present, not aliskiren, but ACEIs or ARBs are the drugs of choice in prevention of cardiovascular events in patients with $\mathrm{EH}$.

\section{Summary}

Essential hypertension-induced cardiovascular diseases are a common cause of death among the worldwide population. Blockade of RAAS, which plays a major role in developing $\mathrm{EH}$, is suboptimal when using ACEI and/or ARB. The key, rate-limiting step reaction of the RAAS cascade can be inhibited pharmacologically by using aliskiren, which successfully decreases BP and has a positive effect on organ damage caused by EH. There are groups of patients for whom complex therapy with ACEI or ARB and aliskiren is not recommended. Further long-term studies on large groups of patients are required to precisely determine the place of aliskiren in antihypertensive therapy. 


\section{References}

1. Ezzati M, Lopez AD, Rodgers A, Vander Hoorn S, Murray CJL; the Comparative Risk Assessment Collaborating Group (2002). Comparative Risk Assessment Collaborating Group. Selected major risk factors and global and regional burden of disease. Lancet 2002; 360: 1347-60.

2. Fields LE, Burt VL, Cutler JA, Hughes J, Roccella EJ, Sorlie P. The burden of adult hypertension in the United States 1999 to 2000: a rising tide. Hypertension 2004; 44: 398404.

3. Chobanian AV, Bakris GL, Black HR, et al. The Seventh Report of the Joint National Committee on Prevention, Detection, Evaluation, and Treatment of High Blood Pressure: the JNC 7 Report. JAMA 2003; 289: 2560-72.

4. Zdrojewski T, Drygas W, Naruszewicz M, et al. Rozpowszechnienie i kontrola nadciśnienia tętniczego w Polsce - porównanie z wybranymi krajami w Europie i na całym świecie. In: Hipertensjologia [Polish]. Więcek A, Januszewicz A, Szczepańska-Sadowska E, et al. Medycyna Praktyczna, Krakow 2011; 1-5.

5. Report of a WHO consultation on obesity. Preventing and managing the global epidemic. Division of non communicable diseases. World Health Organization. Geneva 3-5 June 1997. WHO/NUT/NCD 1998.

6. Barylski M, Małyszko J, Rysz J. Lipids, blood pressure, kidney - what was new in 2011? Arch Med Sci 2011; 7: 1055-66.

7. Banach M, Michalska M, Kjeldsen SE, Małyszko J, Mikhailidis DP, Rysz J. What should be the optimal levels of blood pressure: does the J-curve phenomenon really exist? Expert Opin Pharmacother 2011; 12: 1835-44.

8. Aronow WS. What should the optimal blood pressure goal be in patients with diabetes mellitus or chronic kidney disease? Arch Med Sci 2012; 8: 399-402.

9. SOLVD Investigators. Effect of enalapril on survival in patients with reduced left ventricular ejection fraction and congestive heart failure. N Engl J Med 1991; 325: 293-302.

10. Ramser J, Atidi FE, Burckle CA, et al. A unique exonic splice enhancer mutation in a family with $x$-linked mental retardation and epilepsy points to a novel role of the renin receptor. Hum. Molecular Genetics 2005; 4: 1019-27.

11. Büchler FR, Laragh JH, Baer L, Vaughan ED Jr, Brunner HR. Propranolol inhibition of renin secretion: a specific approach to diagnosis and treatment of renin-dependent hypertensive diseases. N Engl J Med 1972; 287: 1209-14.

12. Wood JM, Cumin F, Maibaum J. Pharmacology of renin inhibitors and their application to the treatment of hypertension. Pharmacol Ther 1994; 61: 325-44.

13. Ondetti MA, Rubin B, Cushman D. Design of specific inhibitors of angiotensin-converting enzyme: new class of orally active antihypertensive agents. Science 1977; 196: 441-4.

14. Brunner HR, Gavras H, Laragh JH, Keenan R. Hypertension in man: exposure of the renin and sodium components using angiotensin II blockade. Circ Res 1974; 24 (Suppl. I): 135-43.

15. Alderman MH, Ooi WL, Cohen $\mathrm{H}$, et al. Plasma renin activity: a risk factor for myocardial infarction in hypertensive patients. Am J Hypertens 1997; 10: 1-8.

16. Kehoe B, Keeton GR, Hill C. Elevated plasma renin activity associated with renal dysfunction. Nephron 1986; 44 : 51-7.

17. Malmqvist K, Ohman KP, Lind L, Nyström F, Kahan T. Relationships between left ventricular mass and the re- nin-angiotensin system, catecholamines, insulin and leptin. J Intern Med 2002; 252: 430-9.

18. Hollenberg NK, Fisher ND, Price DA. Pathways for angiotensin II generation in intact human tissue: evidence from comparative pharmacological interruption of the renin system. Hypertension 1998; 32: 387-92.

19. Seggs LT, Kahn JR, Lentz KE, Shumway NP. The preparation, purification and amino acid sequence of a polypeptide renin substrate. J Exp Med 1957; 106: 439-53.

20. Rongen GA, Lenders JW, Smits P, Thien T. Clinical pharmacokinetics and efficacy of renin inhibitors. Clin Pharmacokinet 1995; 29: 6-14.

21. Van Paassen P, de Zeeuw D, de Jong PE. Renal and systemic effects of the renin inhibitor remikiren in patients with essential hypertension. J Cardiovasc Pharmacol 1995; 26: 39-45.

22. Märki HP, Binggeli A, Bittner B. Piperidine renin inhibitors: from leads to drug candidates. Farmaco 2001; 56: 21-7.

23. Lefevre G, Duval M, Poncin A. Direct micro-radioimmunoassay of the new renin inhibitor CGP60536. J Immunoassay 2000; 21: 65-84.

24. Maibaum J, Feldman DL. Renin inhibitors as novel treatments for cardiovascular disease. Expert Opin Ther Patents 2003; 13: 589-603.

25. Staessen JA, Li Y, Richart T. Oral renin inhibitors. Lancet 2006; 368: 1449-56.

26. Wood JM, Maibaum J, Rahuel J, et al. Structure-based design of aliskiren, a novel orally effective renin inhibitor. Biochem Biophys Res Commun 2003; 308: 698-705.

27. Nussberger J, Wuerzner G, Jensen C, Brunner HR. Angiotensin II suppression in humans by the orally active renin inhibitor aliskiren (SPP100). Comparison with enalapril. Hypertension 2002; 39: E1-8.

28. Dieterle W, Corynen S, Mann J. Effect of the oral renin inhibitor aliskiren on the pharmacokinetics and pharmacodynamics of a single dose of warfarin in healthy subjects. Br J Clin Pharmacol 2004; 58: 433-6.

29. Vaidyanathan S, Reynolds C, Yeh CM, et al. Pharmacokinetics, safety, and tolerability of the novel oral direct renin inhibitor aliskiren in elderly healthy subjects. J Clin Pharmacol 2007; 47: 453-60.

30. Azizi M, Menard J, Bissery A, et al. Pharmacologic demonstration of the synergistic effects of a combination of the renin inhibitor aliskiren and the AT1 receptor antagonist valsartan on the angiotensin II-renin feedback interruption. J Am Soc Nephrol 2004; 15: 3126-33.

31. Stanton A, Jensen C, Nussberger J, O'Brien E. Blood pressure lowering in essential hypertension with an oral renin inhibitor, aliskiren. Hypertension 2003; 42: 1137-43.

32. Gradman AH, Schmieder RE, Lins RL, Nussberger J, Chiang Y, Bedigian MP. Aliskiren, a novel orally effective renin inhibitor, provides dose-dependent antihypertensive efficacy and placebo-like tolerability in hypertensive patients. Circulation 2005; 111: 1012-8.

33. Januszewicz W, Więcek A, Prejbisz A, et al. Inhibitory reniny w terapii nadciśnienia tętniczego. In: Leki hamujące aktywność układu renina-angiotensyna-aldosteron w chorobach serca, naczyń i nerek [Polish]. Medycyna Praktyczna, Krakow 2010; 280-1.

34. Musini VM, Fortin PM, Bassett K, Wright JM. Blood pressure lowering efficacy of renin inhibitors for primary hypertension: a Cochrane systematic review. J Hum Hypertens 2009; 23: 495-502.

35. Gao D, Ning N, Niu X, et al. Aliskiren vs. angiotensin receptor blockers in hypertension: meta-analysis of randomized controlled trials. Am J Hypertens 2011; 24: 613-21. 
36. Gradman AH, Weir MR, Wright M, Bush CA, Keefe DL. Efficacy, safety and tolerability of aliskiren, a direct renin inhibitor, in women with hypertension: a pooled analysis of eight studies. J Hum Hypertens 2010; 24: 721-9.

37. Stanton AV, Gradman AH, Schmieder RE, Nussberger J, Sarangapani R, Prescott MF. Aliskiren monotherapy does not cause paradoxical blood pressure rises: meta-analysis of data from 8 clinical trials. Hypertension 2010; 55: 54-60.

38. Fogari R, Zoppi A, Mugellini A, Derosa G. Different effects of aliskiren and losartan on fibrinolysis and insulin sensitivity in hypertensive patients with metabolic syndrome. Horm Metab Res 2010; 42: 892-6.

39. Chou CL, Lai YH, Lin TY. Aliskiren prevents and ameliorates metabolic syndrome in fructose-fed rats. Arch Med Sci 2011; 7: 882-8.

40. Stucchi P, Cano V, Ruiz-Gayo M, Fernandez-Alfonso MS. Aliskiren reduces body-weight gain, adiposity and plasma leptin during diet induced obesity. Br J Pharmacol 2009; 158: 771-8.

41. Solomon SD, Appelbaum E, Manning WJ, et al. Aliskiren in Left Ventricular Hypertrophy (ALLAY) Trial Investigators: effects of the direct renin inhibitor aliskiren, the angiotensin receptor blocker losartan, or both on left ventricular mass in patients with hypertension and left ventricular hypertrophy. Circulation 2009; 119: 530-7.

42. McMurray JJ, Pitt B, Latini R. Aliskiren Observation of Heart Failure Treatment (ALOFT) Investigators. Effects of the oral direct renin inhibitor aliskiren in patients with symptomatic heart failure. Circ Heart Fail 2008; 1: 17-24.

43. Parving HH, Persson F, Lewis JB, Lewis EJ, Hollenberg NK. AVOID Study Investigators: Aliskiren combined with losartan in type 2 diabetes and nephropathy. N Eng J Med 2008; 358: 2433-46.

44. Persson F, Rossing P, Reinhard $H$, et al. Renal effects of aliskiren compared with and in combination with irbesartan in patients with type 2 diabetes, hypertension, and albuminuria. Diabetes Care 2009; 32: 1873-9.

45. White WB, Bresalier R, Kaplan AP, et al. Safety and tolerability of the direct renin inhibitor aliskiren in combination with angiotensin receptor blockers and thiazide diuretics: a pooled analysis of clinical experience of 12,942 patients. J Clin Hypertens (Greenwich) 2011; 13: 506-16.

46. European Medicines Agency recommends new contraindications and warnings for aliskiren-containing medicines. EMA/CHMP/112042/2012. www.ema.europa.eu

47. Moist L. Aliskiren plus ACEIs or ARBs increases hyperkalemia more than aliskiren, ACEls, or ARBs alone. Ann Intern Med 2012; 156: JC6-9.

48. Harel Z, Gilbert C, Wald R, et al. The effect of combination treatment with aliskiren and blockers of the reninangiotensin system on hyperkalaemia and acute kidney injury: systematic review and meta-analysis. BMJ 2012; 344: e42.

49. Tylicki L, Lizakowski S, Rutkowski B. Renin-angiotensinaldosterone system blockade for nephroprotection: current evidence and future directions. J Nephrol 2012; 25: 900-10. 